\title{
Hubungan Kehamilan Remaja dengan Lama Kala II Persalinan Wilayah Kerja Puskesmas Wringin
}

Khoirul Anam

Fakultas IImu Kesehatan Universitas Islam Jember email: -

\begin{abstract}
Abstrak
Kehamilan remaja adalah proses fertilisasi yang terjadi secara alami dengan usia kurang dari 20 tahun, hal itu menjadikan penyebab utama kematian ibu pada saat melahirkan adalah usia ibu yang masih terlalu muda. Di Puskesmas Wringin Bondowoso, masih banyak ditemukan ibu hamil dengan usia dibawah 20 tahun. Penelitian ini bertujuan untuk mengidentifikasi remaja yang hamil di antara usia 13-19 tahun, yaitu hubungan kehamilan remaja dengan lamanya kala II persalinan. Metode penelitian yang digunakan adalah analisis korelasi, dengan populasi seluruh remaja yang hamil dan melahirkan di wilayah Puskesmas Wringin Bondowoso. Besar sampel yaitu sejumlah 21 remaja diambil sebagai sampel, variabel pengukurang menggunakan lembar observasi dan lembar partograf. Nilai masing-masing subjek dipelajari dan didata dalam bentuk angka dan persentase. Berdasarkan hasil dari Spearman's Correlation Test didapatkan bahwa ada hubungan antara kehamilan remaja dan kala II memanjang saat melahirkan. Berdasarkan hasil ini, dapat disimpulkan bahwa kehamilan remaja dapat terjadi karena kurang pengetahuan akan resiko tinggi kehamilan remaja.

Kata kunci: kehamilan rmaja, kala II memanjang.
\end{abstract}

Abstract
Teenage pregnancy is the process of fertilization in order to continue the descent that occurs naturally at the age of less than 20 years, therefore one of the causes of maternal death during pregnancy and childbirth is the age of the mother who is too young. But the reality of the health centers in the region still Wringin Bondowoso umumya many pregnant women under 20 years old. This study aimed to identify the age of pregnant teenagers between the ages of 13-19 years, had stage II in identifying young women who become pregnant between the ages of 13 19 years, knowing their relationship with their teens had stage II. The research method used is analytical correlation, with a population of all pregnant teenagers who gave birth in the territory of Health Center Wringin Bondowoso. Large sample as many as 21 people in total take by way of sampling, the measurement variables using observation sheets and sheets partograph. The value of each - each subject studied and summed in the form of numbers and percentages. Based on the results of Spearman correlation test revealed that the relationship between teenage pregnancy with the length of stage II. Based on these results we can conclude that pregnancy can occur because of lack of knowledge about high risk pregnancy mothers at a young age.

Keywords: teenage pregnancy, length of stage II

\section{Pendahuluan}

Kehamilan merupakan suatu proses pembuahan dalam rangka melanjutkan keturunan yang terjadi secara alami, menghasilkan janin yang tumbuh di dalam rahim ( Manuaba, 2012). Proses kehamilan merupakan mata rantai yang berkesinambungan, yang terdiri dari pelepasan ovum, terjadi migrasi spermatozoa dan ovum, terjadi konsepsi dan pertumbuhan zigot, terjadi nidasi (implantasi uterus), pembentukan placenta tumbuh kembang hasil konsepsi sampai aterm (Manuaba, 2015).

Masa remaja adalah masa sejak puber sampai saat dimana anak itu telah mencapai kedewasaan baik psikologis, seksual, maupun physiologis (Manuaba, 2015). Batasan usia remaja yang umum digunakan oleh para ahli adalah antara 12 sampai 21 tahun. Rentan waktu usia remaja ini biasanya dibedakan atas tiga, yaitu : $12-15$ tahun = masa remaja awal, $15-18$ tahun = masa remaja pertengahan, dan $18-21$ tahun = masa remaja akhir (Desmita, 2014).

Jumlah kematian ibu disebabkan pada masa kehamilan dan persalinan diantaranya disebabkan oleh usia ibu pada saat kehamilan. Seiring berkembangnya ilmu pengetahuan yang sangat pesat, diikuti pula dengan tingginya angka kehamilan pada remaja.

Kehamilan pada usia remaja akan memberikan dampak yang kurang baik karena dapat berpengaruh pada proses persalinan yang dapat membahayakan ibu maupun janinnya.

Mortalitas pada wanita hamil dan bersalin adalah masalah terbesar di negara berkembang. Ini berarti kemampuan untuk memberikan pelayanan kesehatan masih memerlukan perbaikan kesehatan yang bersifat menyeluruh dan lebih bermutu. Kematian ibu pada SKDI 2012 terdata 359 per 100.000 kelahiran hidup dan angka kematian perinatal adalah 32 per 1000 kelahiran hidup ( 
SKDI,2012). Di Provinsi Jawa Timur dalam Tahun 2012, 2011, 2010, di dapatkan angka kematian Ibu per 100.000 kelahiran hidup berturut-turut $106,5 \quad ; \quad 92,8 ; \quad 89,3$ (Rochajati,2013).

Angka Kematian Ibu (AKI) di Bondowoso pada tahun 2016 berjumlah 9 orang. Berdasarkan pra survey yang telah dilakukan oleh penulis di Wilayah Kerja Puskesmas Wringin Kabupaten Bondowoso Tahun 2016, didapatkan dari 10 ibu remaja hamil yang melahirkan terdapat 5 (50\%) ibu remaja melahirkan mengalami persalinan lama melampaui batas perhitungan partograf, 3 $(30 \%)$ ibu remaja melahirkan mengalami perdarahan, dan 2 (20\%) ibu remaja melahirkan normal.

Salah satu upaya yang dilakukan pemerintah untuk menanggulangi hal tersebut melalui undang - undang perkawinan yaitu pembatasan usia menikah pada wanita minimal 18 tahun dan pria 20 tahun. Salah satu upaya Departemen Kesehatan untuk menurunkan angka kehamilan pada remaja diantaranya dengan dampak penyakit akibat hubungan seksual, penyuluhan tentang bahaya kehamilan pada remaja yang berpengaruh pada proses persalinannya. pengenalan pendidikan seksual sejak dini di sekolah, penyuluhan dan sosialisasi. Maka dari permasalahan di atas penulis tertarik untuk melakukan penelitian yang berjudul Hubungan Kehamilan Remaja Dengan Lama Kala II Persalinan di Wilayah Kerja Puskesmas Wringin Kabupaten Bondowoso.

\section{Metode Penelitian}

Penelitian ini menggunakan jenis penelitian analitik korelasi. Dalam penelitian ini bertujuan mengetahui hubungan kehamilan remaja dengan lama persalinan kala II di Wilayah Kerja Puskesmas Wringin Kabupaten Bondowoso. Populasi yang akan di gunakan dalam penelitian adalah semua ibu hamil remaja yang melahirkan pada bulan Apri - Mei 2018

Sampel dalam penelitian ini adalah ibu hamil remaja primi yang melahirkan dengan jumlah 21 ibu remaja hamil primi yang melahirkan di Wilayah Kerja Puskesmas Tahun 2018. Dalam penelitian ini teknik pengambilan sampel menggunakan Non Probability Sampling jenis Consecutive Sampling, yaitu cara pengambilan sampel ini dilakukan dalam memilih sampel yang memenuhi kriteria sampai kurun waktu tertentu sehingga jumlah sampel terpenuhi (Hidayat, 2008).

Instrumen penelitian yang digunakan adalah data sekunder, yaitu lembar partograf dan lembar observasi dari ibu hamil remaja yang bersalin di Wilayah Kerja Puskesmas Wringin Kabupaten Bondowoso.

\section{Hasil Dan Pembahasan}

Hasil

Untuk menguji lama persalinan kala II pada remaja maka analisis dilakukan dalam bentuk analisis univariat.

Tabel 1. Hubungan kehamilan remaja dengan lama kala II di wilayah kerja Puskesmas Wringin Kabupaten bondowoso bulan April - Mei 2018.

\begin{tabular}{|c|c|c|c|c|c|c|}
\hline \multirow{2}{*}{$\begin{array}{l}\text { Usia } \\
\text { Keha } \\
\text { milan } \\
\text { Rema } \\
\text { ja }\end{array}$} & \multicolumn{5}{|c|}{ Lama Kala II } & \multirow[b]{2}{*}{ Jumlah } \\
\hline & $\begin{array}{l}91- \\
100\end{array}$ & $\begin{array}{l}101 \\
- \\
110\end{array}$ & $\begin{array}{l}111- \\
120\end{array}$ & $\begin{array}{l}121- \\
130\end{array}$ & $\begin{array}{l}13 \\
1- \\
14 \\
0\end{array}$ & \\
\hline $\begin{array}{l}15 \\
16\end{array}$ & $\begin{array}{l}- \\
1\end{array}$ & & - & $\begin{array}{l}1 \\
(4,76)\end{array}$ & $\begin{array}{l}- \\
-\end{array}$ & $\begin{array}{l}1(4,76) \\
2(9,52)\end{array}$ \\
\hline $\begin{array}{l}17 \\
18\end{array}$ & $\begin{array}{l}1 \\
(4,76) \\
-\end{array}$ & $\begin{array}{l}- \\
- \\
1 \\
(4,7\end{array}$ & $\begin{array}{l}- \\
2 \\
(9,52) \\
2\end{array}$ & $\begin{array}{l}1 \\
(4,76) \\
-\end{array}$ & $\begin{array}{l}- \\
-\end{array}$ & $\begin{array}{l}3 \\
(14,28) \\
6\end{array}$ \\
\hline 19 & $\begin{array}{l}1 \\
(4,76)\end{array}$ & 6) & $\begin{array}{l}(9,52) \\
-\end{array}$ & $\begin{array}{l}3 \\
(14,2 \\
8) \\
4 \\
(19,0 \\
4)\end{array}$ & $\begin{array}{l}4 \\
(1 \\
9, \\
04 \\
)\end{array}$ & $\begin{array}{l}(28,57) \\
9 \\
(42,85)\end{array}$ \\
\hline $\begin{array}{l}\text { Jumla } \\
\mathrm{h}\end{array}$ & $\begin{array}{l}3 \\
(14,2 \\
8)\end{array}$ & $\begin{array}{l}1 \\
(4,7 \\
6)\end{array}$ & $\begin{array}{l}4 \\
(19,0 \\
4)\end{array}$ & $\begin{array}{l}9 \\
(42,8 \\
5)\end{array}$ & $\begin{array}{l}4 \\
(1 \\
9, \\
04\end{array}$ & $100 \%$ \\
\hline
\end{tabular}

Dari tabel di atas menunjukkan bahwa dari 21 responden sebagian kecil mengalami lama kala II 91 - 100 menit berjumlah 3 orang $(14,28 \%)$, dan sebagian besar mengalami lamakala II 121- 130 menit berjumlah 9 orang $(42,85 \%)$. Penelitian ini menunjukkan bahwa semakin tua usia maka semakin lama mengalami kala II.

\section{Pembahasan}

\section{Kehamilan Remaja Berdasarkan Usia}

Pada hasil penelitian yang bisa dilihat pada tabel diatas menunjukkan bahwa sebagian besar responden $42,85 \%$ berusia 19 tahun.Usia yang relatif muda (20 tahum kebawah) dapat mempengaruhi kehamilan dan persalinannya nanti. Bila kehamilan itu diteruskan dalam usia relatif muda dari sudut ilmu kebidanan dapat mengakibatkan penyulit (komplikasi) kehamilan yang cukup besar diantaranya persalinan yang cukup bulan (prematuritas), pertumbuhan janin dalam rahim yang kurang sempurna, kehamilan dengan keracunan yang memelurkan penanganan khusus, persalinan sering berlangsung dengan tindakan oprasi, perdarahan setelah melahirkan makin meningkat, kembalinya alat reproduksi yang terlambat setelah melahirkan, mudah terjadi infeksi setelah persalinan (Manuaba, 2015). Kehamilan remaja di usia yang relatif muda terdapat banyak resiko, maka upaya yang harus dilakukan adalah menganjurkan pasangan suami istri muda 
untuk menggunakan metode keluarga berencana (KB) yang aman dan bersih. Upaya preventif ini bertujuan untuk menyelamatkan alat reproduksi remaja.

Kehamilan Remaja Berdasarkan Lama Kala II

Berdasarkan hasil penelitian pada

tabel dijelaskan bahwa sebagian besar ibu remaja hamil yang melahirkan mengalami lama kala II 121-130 menit sebanyak 9 orang $(42,85 \%)$. Kemungkinan besar hal ini dikarenakan usia ibu yang terlalu muda.

Dampak kehamilan usia dibawah 20 tahun antara lain, perdarahan pada saat melahirkan yang disebabkan oleh otot rahim yang terlalu lemah dalam proses involusi, proses pembekuan darah yang lambat, dan juga dipengaruhi oleh robekan pada jalan lahir. Persalinan lama dan sulit yang disebabkan oleh kelainan letak janin, kelainan panggul, kelainan kekuatan his dan mengedan, serta pimpinan persalinan yang salah. Kematian ibu pada saat melahirkan disebabkan oleh perdarahan dan infeksi (Manuaba, 2015).

Penyulit pada kehamilan remaja lebih tinngi dibandingkan ibu hamil diatas 20 tahun, keadaan ini disebabkan belum matangnya alat reproduksi untuk hamil sehingga dapat merugikan kesehatan ibu maupun perkembangan pertumbuhan janinnya nanti.

Hubungan Kehamilan Remaja Dengan Lama Kala II

Pada analisis data tekhnik Spearman Rho diperoleh nilai $Z$ hitung $>Z$ tabel, yang menunjukkan adanya korelasi (-) yang artinya ada hubungan antara kehamilan remaja dengan lama kala II diwilayah kerja Puskesmas Wringin Kabupaten Bondowoso bulan April- Mei 2018. Dimana pada teori di jelaskan bahwa semakian muda usia semakin lama mengalami kala II, sedangkan pada hasil penelitian menunjukkan bahwa semakin tua usia semakin lama mengalami lama kala II 121-130 menit sebanyak 9 orang (42.85\%). Yaitu terjadi pada usia 19 tahun sebanyak 9 orang $(42,85 \%)$.

Kehamilan remaja merupakan proses pembuahan dalam rangka melanjutkan keturunan yang terjadi secara alami, menghasilkan janin yang tumbuh didalam rahim ibu yang berusia dibawah 20 tahun (Prawirohardjo, 2013). Kala II merupakan kala pengeluaran janin, waktu uterus dengan kekuatan his ditambah kekuatan mengedan mendarang janin hingga lahir (Mochtar. 2012). Akibat resiko tinggi kehamila remaja usia dibawah 20 tahun antara lain mengalami perdarahan, persalinan yang lama dan sulit (Prawirohardjo, 2006). Menurut peneliti, adanya hubungan antara kehamilan remaja dengan lama kala II disebabkan oleh usia yang terlalu muda, kekuatan his dan mengedan serta pimpinan persalinan yang salah.

\section{Kesimpulan Dan Saran}

Berdasarkan hasil penelitian dapat disimpulkan ada hubungan antara kehamilan remaja dengan lama kala II yaitu semakin tua usia maka semakin lama mengalami kala II. Bidan diharapkan melakukan pendekatan secara mendalam dan memberikan konseling pada pasangan suami istri yang masih muda untuk mengikuti program KB.

\section{Daftar Pustaka}

Desmita. 2014." Psikolagi

Hidayat, AA. 2008." Metode Penelitian Keperawatan dan Teknik Analisis Data".

Jakarta : Salemba Medika

Manuaba, Ida Bagus. 2012." IImu Kebidanan, Penyakit Kandungan \& Keluarga

Berencana untuk Pendidikan Bidan". Jakarta : EGC.

Manuaba, Ida Bagus. 2015." Memahami Kesehatan Reproduksi Wanita". Jakarta :Arcan.

Perkembangan". Bandung :PT Remaja Rosdakarya.

Mochtar, Rustam. 2012." Sinopsis Obstetri Jilid 1". Jakarta : EGC.

Prawirohardjo, Sarwono. 2013. "Buku Praktis Pelayanan Kesehatan Maternal dan Neonatal"Jakarta . YBPSP.

Prawirihardjo, Sarwono. 2006." Buku Acuan Nasional Pelayanan Kesehatan Maternal dan Neonatal”. Jakarta : YBPSP.

Prawirihardjo, Sarwono. 2006. " IImu Kebidanan". Jakarta "YBPSP.

Rochjati, Poedji. 2013." SKRINING ANTENATAL pada Ibu Hamil Pengenalan

Faktor Resiko Deteksi Dini lbu Hamil Resiko Tinggi". Surabaya: Airlangga University Press. 